\title{
Dentist suicides
}

\author{
Introduction by J. Renshaw ${ }^{1}$
}

Please send any ideas for feature articles for
consideration to:
Ruth Doherty,
Managing Editor,
British Dental Journal,
The Macmillan Building,
4-6 Crinan Street,
London,
N19XW
Email: r.doherty@nature.com

Email: r.doherty@nature.com

Editor's comment: The following article highlights the very sad circumstances surrounding the suicide of a colleague earlier in the year. We received the text below from Paul Hood as a submission to 'Letters to the editor' for the BDJ and reproduce it here in full. My initial reaction was that the letter contained sentiments and thoughts that would resonate with readers but that it over long for our pages and needed some general 'tidying up' before we could publish it. I replied by e-mail suggesting this and offering editorial help if he wished. Very sadly I did not receive a reply as Paul had committed suicide. Subsequently John Renshaw contacted me and suggested that we might publish the letter together with an introduction. We do this, with full, and gratefully received, permission from Paul's widow, to whom we also extend our sincere condolences.

\section{INTRODUCTION}

Dentists have a reputation for being a high risk group for suicide. Recent evidence from coroners' courts does not seem to bear this out. It may have been true in the past but suicide is pretty rare among our profession these days, although it does happen. I am always upset to hear of any colleague who dies, but this way of ending one's life is the most painful.

Imagine my horror at being asked through my consultancy company to help a colleague whose husband had died at his own hand last December. There had been severe problems with the Primary Care Trust (PCT) and the whole thing got too much for him. Tragically, he left behind his wife and three young children. They are struggling to cope with the aftermath, not helped by the PCT, in my opinion.

Having been associated for many years with the Sick Dentists' Scheme I knew of one or two previous suicide cases and I wondered if this new case bore any similarities to other recent suicides.

General Dental Practitioner, Scarborough Correspondence to: John Renshaw Email:jrsteeth@gmail.com

\section{Refereed Paper}

Accepted 6 November 2013

DOI: 10.1038/sj.bdj.2013.1144

${ }^{\circledR}$ British Dental Journal 2013; 215: 593-594
I asked for help and information through the internet and discovered two other similar cases in the last 12 months - all three directly linked to PCT activity. The $B D J$ 's Editor-in-Chief has agreed to print a letter in this issue that came from one of those victims shortly before his death. It makes chilling reading. The back stories linked to these victims are truly horrifying.

The BDA's General Dental Practice Committee, through its leader, John Milne, has asked the Minister of State for Health to open an enquiry into this group of deaths and the role played in them by the three different PCTs.

I believe that enquiry is absolutely essential. The people whose behaviour may have led to these deaths should be made every bit as accountable for their actions as they expect our professional colleagues to be for theirs.

It's time for some pretty ugly chickens to come home to roost.

\section{LETTER TO THE \\ EDITOR FROM PAUL HOOD}

\section{DESPAIR!!}

I qualified BDS in 1984. Over the past 28 years I have watched our profession being slowly strangled by bureaucracy and now I am at the point of complete despair. I shall explain using a simple example which I am sure occurs in every dental practice at least daily.
Patient X (a patient of the dentist for 18 years) rings up to say that they have broken a tooth. The receptionist looks at the diary but there is no space at all. However, as we never turn away our patients who are in trouble, patient $\mathrm{X}$ is offered an appointment where they will have to 'sit and wait' hoping that the dentist will gain some space. The patient agrees to this.

The dentist manages to get patient $\mathrm{X}$ in after a short wait and discovers that the distal box of a 20-year-old MOD amalgam in an upper premolar tooth has broken off. The tooth is sensitive to hot/cold but looks otherwise sound. A glass ionomer temporary restoration is placed and the patient is invited to make an appointment, having been given a printed estimate to return for the definitive restoration. The patient is very grateful for being seen so quickly and for the pain relief provided by the temporary restoration and makes the required appointment. NO money or UDAs have been claimed for this appointment. This is the much maligned NHS working as it should.

Outcome... very satisfied patient feeling that they have been treated promptly, efficiently and with respect.

HOWEVER, the dentist has broken so many 'rules' that should this be investigated by the GDC or a law firm 


\section{BDJ FEATURE}

the dentist runs the risk of a suspension!!

Why?

1. Failure to take a full medical history including alcohol intake and social history (been a patient for 18 years so we know them)

2. Failure to carry out a full mouth inspection including extra-oral tissues (been a patient for 18 years so we know them)

3. Failure to carry out a multipoint periodontal charting (been a patient for 18 years so we know them)

4. Failure to discuss every other treatment option including extraction despite having had the original amalgam for 20 years asymptomatically

5. Failure to get the patient's permission to use a local anaesthetic on the definitive restoration appointment (this will also then lead to a failure to record the batch number of the LA) despite the patient having had
LA for the other 20 restorations in their mouth

6. Failure to take a radiograph of the tooth (been a patient for 18 years so we have full records including radiographs).

The list goes on and on, but the patient is really happy with the treatment. And that is what should matter.

At what point are we likely to see a return to common sense and logic in the treatment of dental patients and not this slavish need to tick boxes, which is favoured by those 'academics' who have never tried to treat $40+$ patients daily and who are so litigation conscious that they will do nothing unless a full risk assessment has been carried out first? Will every appointment in the future be preceded by 30 minutes of intense questioning before we actually get down to treating the one person who matters, the patient? Who is going to pay for my valuable time if I see10 patients/day rather than the 40 I currently see?

On questioning over 100 patients since the beginning of January 2013 not one patient cares one iota about the paperwork. In fact many are offended at the thought of being asked the sort of questions being suggested. They want to know exactly what their alcohol intake matters when I am just going to repair a tooth. We are GDPs, NOT GMPs!! I can’t argue with their logic on that one.

We do not kill patients. Dr Harold Shipman did. It is claimed that midStaffordshire hospitals did. Neglect and apathy do. We don't.

Is this the end for the sort of good quality, ethical dentistry intended to provide the best for the PATIENT, the one person who seems to have been forgotten by the PCT, CQC etc? Surely patients come first? Apparently not.

Paul Hood Andover 